\title{
Nanocatalysts for Ethanol Oxidation. Synthesis and Characterisation
}

\author{
A. Bonesi, W.E. Triaca, AM. Castro Luna * \\ INIFTA, Facultad de Ciencias Exactas, Universidad Nacional de La Plata, Suc. 4, CC 161900, \\ La Plata, Argentina
}

Received 25 April 2008; Accepted 10 December 2008

\begin{abstract}
Carbon-supported binary $\mathrm{PtSn} / \mathrm{C}$ and ternary $\mathrm{PtSnNi} / \mathrm{C}$ catalysts were prepared for the electro-oxidation of ethanol. The carbon-supported nanoparticles were synthesised by employing a modified polyol methodology and characterised in terms of structure, morphology and composition by using XRD, EDX and TEM techniques. Their electrocatalytic behaviour for ethanol oxidation (EO) was investigated by employing a disccomposite electrode covered by a thin layer of catalyst imbedded in a Nafion polymer electrolyte film. An enhancement of the EO through a negative shift of the onset oxidation potential and higher current density at constant potentials were observed on the $\mathrm{PtSnNi} / \mathrm{C}$ electrodes as compared to those for $\mathrm{PtSn} / \mathrm{C}$ electrodes. The temperature was changed in the range $40{ }^{\circ} \mathrm{C} \leq \mathrm{t} \leq 80{ }^{\circ} \mathrm{C}$, and the variation of the activation energy calculated by linear regression of the Arrhenius plots.
\end{abstract}

Keywords: tin, nickel, platinum, ethanol, polyol, catalyst.

\section{Introduction}

Fuel cells are attractive devices to easily convert chemical energy into electricity. Especially those that employ PEM technology and work at low temperatures are potential tools for portable systems.

Many studies have been conducted using methanol as anode fuel in the DMFC [1]. Unfortunately, there are serious limitations to its utilisation, such as its slow oxidation kinetics, the catalyst poisoning by strongly adsorbed intermediates and the methanol crossover, that disturb the cathodic reaction [2, 3]. Moreover, due to its toxicity, methanol is an environmentally unfriendly compound. In the last

\footnotetext{
* Corresponding author. E-mail address: castrolu@inifta.unlp.edu.ar
} 
years, ethanol from biomass fermentation has been proposed as an alternative ecological fuel.

The ethanol oxidation mechanism has been deeply studied on Pt [4-6], and it has been established that only a small amount of adsorbed ethanol goes to $\mathrm{CO}_{2}$, whereas a great proportion of ethanol goes to acetaldehyde and acetic acid, highlighting that the $\mathrm{C}-\mathrm{C}$ bond is difficult to break [5,6]. Experimental techniques such as differential electrochemical mass and in situ infrared reflectance spectroscopy have identified the surface intermediates on $\mathrm{Pt}$ as $\mathrm{CH}_{3} \mathrm{COH}, \mathrm{CH}_{3} \mathrm{CO}, \mathrm{CH} x$ and $\mathrm{CO}$ [6-8].

The aim of the DEFC researchers is to synthesise a suitable catalyst able to get the maximum conversion efficiency of ethanol into $\mathrm{CO}_{2}$. Recently, a theoretical study on the influence of the modification of the Pt surface structure on EO has been reported taking into account that EO is a structure-sensitive reaction. It has been found that the open surface $\operatorname{Pt}(100)$ is the best facet to fully oxidise ethanol at low coverage [9].

It appears that an improvement in electro-catalytic ethanol oxidation (EO) is possible with multifunctional catalysts. Binary or ternary Pt-based alloys are proposed because each component makes a contribution by: i) providing an adequate Pt-Pt distance to favour adsorption and breaking of the ethanol molecule, ii) providing oxygenated species to facilitate the $\mathrm{CO}$-like adsorbate oxidation, or iii) modifying the electronic structure of $\mathrm{Pt}$ to weaken the Ptadsorbate bond [10].

The addition of $\mathrm{Sn}$ to $\mathrm{Pt}$ enhances the activity for EO, particularly at lower potentials, as compared to that obtained with pure $\mathrm{Pt} / \mathrm{C}$ anode catalysts. Through DEMS, it has been established that $\mathrm{EO}$ at lower potential goes to $\mathrm{CO}_{2}$ and acetaldehyde, whereas at higher potentials the production of $\mathrm{CH}_{3} \mathrm{COOH}$ increases [7]. Lamy et al. studied the electro-oxidation of ethanol on PtSn catalysts with $\mathrm{Pt}: \mathrm{Sn}$ atomic ratios varying from 90:10 to 50:50 at room temperature. A great enhancement of the electro-catalytic activity was observed for non-alloyed PtSn with 10 atom percent (at\%) Sn [11]. Jiang et al. compared the catalytic activity of a partially alloyed $\mathrm{Pt}-\mathrm{Sn}$ catalyst with that of a quasi-nonalloyed $\mathrm{Pt}-\mathrm{SnO}_{2}$ catalyst. The $\mathrm{PtSnO}_{2}$ catalyst showed higher catalytic activity for ethanol electro-oxidation than the PtSn alloy [12]. Colmati et al. found that thermally treated $\left(200{ }^{0} \mathrm{C}\right) \mathrm{PtSn}$ catalysts have a better performance for $\mathrm{EO}$ because the thermal treatment gave rise to the formation of a predominant phase of cubic $\mathrm{Pt}_{3} \mathrm{Sn}$ and to a lesser extent, a hexagonal PtSn phase, the latter showing a poor activity for ethanol oxidation[13].

From a practical point of view, the fuel cell catalysts have to fulfil the requirements of being nanosized particles with uniform composition, high alloy content and high dispersion on the selected support, i.e., Vulcan XC-72R. At present, there is a wide interest in new approaches to obtain nanoparticles of supported catalysts to be used for EO. The methodology usually includes a chemical step to form oxidised colloidal particles, followed by another step to reduce and deposit the catalysts on the carbon particles [12, 14-15]. 
In this work, new binary and ternary nanoparticle catalysts, synthesised by a modified polyol methodology, were physically and electrochemically characterised for EO.

\section{Experimental}

Supported combined catalysts such as $\mathrm{PtSn} / \mathrm{C}$ and $\mathrm{PtSnNi} / \mathrm{C}$ were synthesised by employing the polyvynilpyrrolidone (PVP), ethylene glycol (EG) and water methodology. [14]. The sequential steps involved in the preparation were: i) a predetermined amount of Vulcan XC-72R was added to the calculated volume of an ethylene glycol, water and PVP solution, the whole mixture was stirred for 5 min; ii) the required precursors, i.e., $\mathrm{PtCl}_{6} \mathrm{H}_{2}, \mathrm{SnCl}_{2}$ and $\mathrm{NiCl}_{2}$, in the required stoichiometric amount, were introduced into the composite mixture giving a colloidal combination of metal oxide-hydroxide, mixed for 15 min to obtain a well dispersed intermediate colloidal solution; iii) the temperature was increased up to $140{ }^{\circ} \mathrm{C}$ and kept constant for $1 \mathrm{~h}$ to allow the nucleation and growth of the metals on the Vulcan support, next the suspension was cooled up and filtered by suction, the solid obtained was washed repeatedly with distilled water, and the product dried at $60{ }^{0} \mathrm{C}$ for $24 \mathrm{~h}$ in a vacuum stove.

All catalysts were characterised according to their particle size, morphology, and composition and dispersion degree by powder X-ray diffraction (XRD), scanning electron microscopy (SEM) and energy dispersive X-ray analysis (EDX).

To study the activity of the catalysts for EO, a glassy carbon disc $\left(0.071 \mathrm{~cm}^{2}\right.$ geometric area) covered by a thin layer of catalyst with a metal loading of 28 $\mu \mathrm{g} / \mathrm{cm}^{2}$ imbedded in a Nafion polymer electrolyte film of $0.1 \mu \mathrm{m}$ was employed. The catalysts were electrochemically characterised employing electrochemical techniques such as cyclic voltammetry, and chronoamperometry. A Pt foil of 1 $\mathrm{cm}^{2}$ geometric area was used as counter electrode and a saturated calomel electrode as reference electrode. In this work, the potentials are referred to that of the reversible hydrogen electrode (RHE). The working electrolyte was $1 \mathrm{M}$ $\mathrm{C}_{2} \mathrm{H}_{5} \mathrm{OH}+0.5 \mathrm{M} \mathrm{H}_{2} \mathrm{SO}_{4}$. The electrochemical experiments were conducted at temperatures varying between $40{ }^{\circ} \mathrm{C}$ and $80{ }^{\circ} \mathrm{C}$. Before the $\mathrm{EO}$ runs, the disccomposite electrode was cycled at $0.10 \mathrm{~V} \mathrm{~s}^{-1}$ between 0.05 and $0.65 \mathrm{~V}$ in a $\mathrm{N}_{2^{-}}$ purged sulphuric electrolyte solution for $5 \mathrm{~min}$ to clean its surface. Real areas were determined by considering the anodic charge involved in the CO-stripping peak by assuming that $\mathrm{CO}$ is linearly adsorbed on one $\mathrm{Pt}$ site and taking into account that $420 \mu \mathrm{C}$ are equivalent to $1 \mathrm{~cm}^{2}$. The CO-stripping voltammogram was run at $0.01 \mathrm{Vs}^{-1}$, after $\mathrm{CO}$ adsorption at $0.05 \mathrm{~V}$ from a $\mathrm{CO}$-saturated $0.5 \mathrm{M}$ $\mathrm{H}_{2} \mathrm{SO}_{4}$ solution for $10 \mathrm{~min}$, and subsequent bubbling of $\mathrm{N}_{2}$ for $10 \mathrm{~min}$. Then, ethanol was added at $0.05 \mathrm{~V}$ and the current-potential curves for $\mathrm{EO}$ were recorded at $0.01 \mathrm{Vs}^{-1}$. Chronoamperometric measurements of $\mathrm{EO}$ at $0.5 \mathrm{~V}$ were also recorded. The current densities are referred to the CO-calculated real area. 


\section{Results and discussion}

\section{Physical characterisation}

For both catalysts, the XRD patterns of synthesised PtSn/C and PtSnNi/C, Fig. 1, show the characteristic peaks of the fcc crystalline Pt. The diffraction peaks at ca. $40^{\circ}, 45^{\circ}, 70^{\circ}$ and $80^{\circ}$ are due to diffraction at the (111), (200), (220) and (311) Pt planes, respectively. The diffraction peaks for PtSn are slightly shifted to lower 2 $\theta$ values with respect to the corresponding peaks for the Pt catalyst [16]. The shift of the peaks to lower angles reveals the alloy formation between Pt and Sn, which is caused by the incorporation of $\mathrm{Sn}$ in the fcc structure of Pt. For PtSnNi, as observed in other ternary catalysts, the presence of a third non-alloyed metal can cause a decrease of the degree of alloying of the binary base alloy with respect to that of the binary catalyst [17].

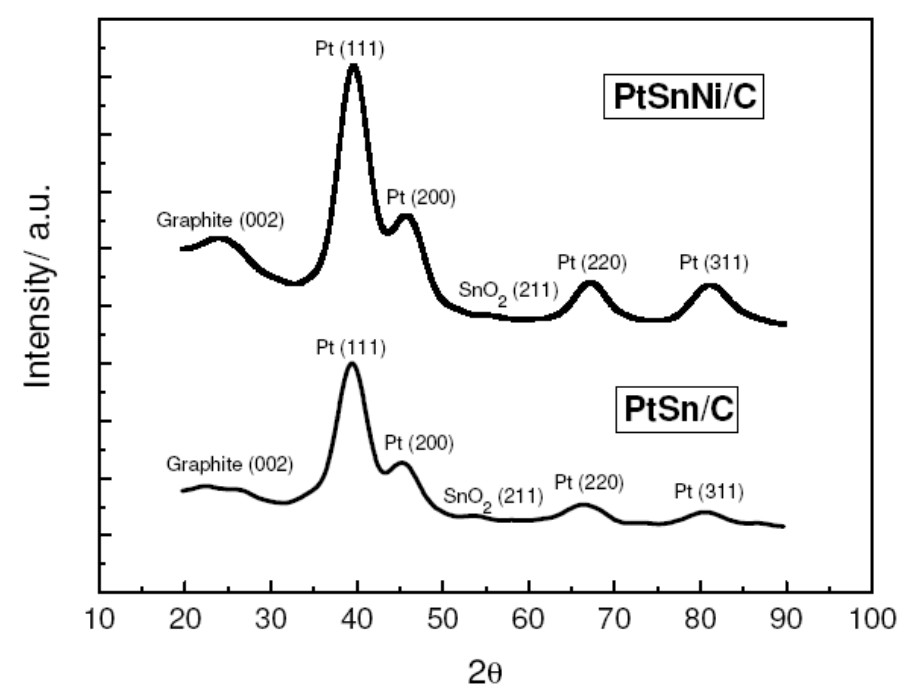

Figure 1. XRD patterns of $\mathrm{PtSn} / \mathrm{C}$ and $\mathrm{PtSnNi} / \mathrm{C}$ catalysts.

There is also a small diffraction peak at around $52^{\circ}$ attributed to $\mathrm{SnO}_{2}$ (211), as reported by Jiang et al. [18]. The presence of a small amount of $\mathrm{SnO}_{2}$ in the vicinity of $\mathrm{Pt}$ nanoparticles can supply oxygen-containing species for the oxidation of adsorbed species from ethanol adsorption on neighbouring Pt sites, enhancing their catalytic activity for EO at low potentials.

Table 1. EDX results for the synthesized catalysts.

\begin{tabular}{|c|c|c|c|}
\hline catalyst & at\% $\mathbf{P t}$ & at\% $\mathbf{~ n}$ & at\% Ni \\
\hline $\mathrm{Pt}-\mathrm{Sn} / \mathrm{C}$ & 57 & 43 & \\
\hline $\mathrm{PtSnNi} / \mathrm{C}$ & 65 & 29 & 6 \\
\hline
\end{tabular}

The average crystallite size of the synthesised nanoparticles was estimated from Scherrer's equation and the (220) diffraction Pt peak, resulting to be about $4 \mathrm{~nm}$ for PtSn and $3 \mathrm{~nm}$ for PtSnNi.

The EDX metal composition in atom percent (at\%) for $\mathrm{PtSn} / \mathrm{C}$ and $\mathrm{PtSnNi} / \mathrm{C}$ catalysts is shown in Table 1 . It can be observed that the ternary catalyst has a lower amount of $\mathrm{Sn}$. 

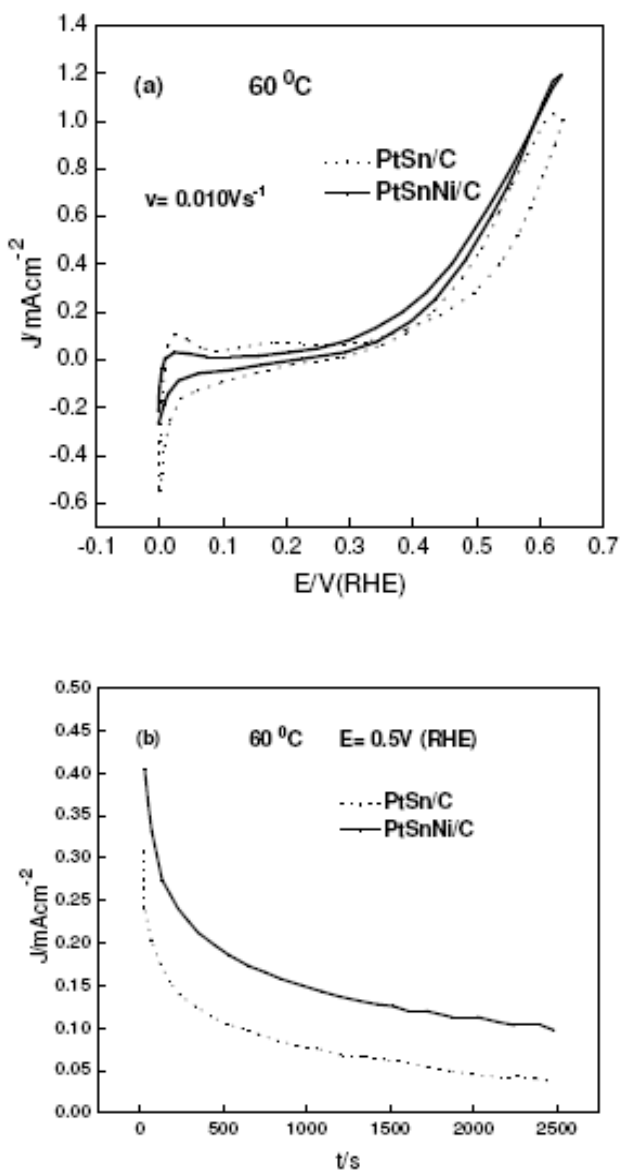

Figure 2. a) Cyclic voltammogram of EO in $1 \mathrm{M} \mathrm{C}_{2} \mathrm{H}_{5} \mathrm{OH}+0.5 \mathrm{M} \mathrm{H}_{2} \mathrm{SO}_{4}$ at $\mathrm{v}=0.01$ $\mathrm{Vs}^{-1} \mathrm{t}=60{ }^{\circ} \mathrm{C}$. (b) Chronoamperometric curves of EO in $1 \mathrm{M} \mathrm{C}_{2} \mathrm{H}_{5} \mathrm{OH}+0.5 \mathrm{M} \mathrm{H}_{2} \mathrm{SO}_{4}$ on $\mathrm{PtSn} / \mathrm{C}$ and $\mathrm{PtSnNi} / \mathrm{C}$ electrodes at $\mathrm{E}=0.5 \mathrm{~V} \mathrm{t}=60^{\circ} \mathrm{C}$.

\section{Electrochemical characterisation}

The electrochemical equipment consisted of a bipotentiostat (Taccussel, type Bi$\mathrm{Pad}$ ), a waveform generator (PARC 173) and an XYt recorder (Houston 2000).

Cyclic voltammograms for $\mathrm{EO}$ in $1 \mathrm{M} \mathrm{C}_{2} \mathrm{H}_{5} \mathrm{OH}+0.5 \mathrm{M} \mathrm{H}_{2} \mathrm{SO}_{4}$ at $60{ }^{\circ} \mathrm{C}$, employing binary $\mathrm{PtSn} / \mathrm{C}$ and ternary $\mathrm{PtSnNi} / \mathrm{C}$ catalysts, are shown in Fig $2 \mathrm{a}$. The PtSnNi/C catalyst lowers the onset potential of ethanol oxidation and increases the current densities at potentials higher than $0.4 \mathrm{~V}$, as compared to the $\mathrm{PtSn} / \mathrm{C}$ catalyst. The transient currents for EO at $0.5 \mathrm{~V}$ are shown in Fig $2 \mathrm{~b}$. For both current-time curves an initial current drop in the first $5 \mathrm{~min}$ is observed, followed by a slower decay, but the current values obtained for $\mathrm{PtSnNi} / \mathrm{C}$ were always higher than those obtained for $\mathrm{PtSn} / \mathrm{C}$.

It has been well established that in binary Pt catalysts, the addition of Sn lowers the onset potential for EO and leads to a slight increase in the activity of the $\mathrm{PtSn} / \mathrm{C}$ catalyst [7]. However, there is not improvement in the selectivity for complete oxidation to $\mathrm{CO}_{2}$, and ethanol oxidation to acetaldehyde and acetic acid prevails. 


\section{Effect of temperature for the EO on PtSn/C and PtSnNi/C}

The effect of different temperatures on the EO was followed by cyclic voltammetry varying the temperature in the $40-80{ }^{\circ} \mathrm{C}$ temperature range. The voltammograms for $\mathrm{EO}$ on $\mathrm{PtSn} / \mathrm{C}$ and $\mathrm{PtSnNi} / \mathrm{C}$ electrodes are shown in Figs. 3a and $3 \mathrm{~b}$, respectively. As can be observed the current density increases as the temperature is increased. At potentials higher than $0.4 \mathrm{~V}$, for PtSn the current density increases less than that of the Ni-containing catalysts when the potential is increased, so at high potentials better performances are obtained with the ternary PtSnNi catalysts.

For the PtSnNi/C electrode, it can also be observed that the EO onset potentials are lower than those for $\mathrm{PtSn} / \mathrm{C}$ catalysts, and at constant potential the current densities are higher in the whole temperature range.

The apparent activation energies for $\mathrm{EO}$ on $\mathrm{PtSn} / \mathrm{C}$ and $\mathrm{PtSnNi} / \mathrm{C}$ catalysts were obtained at different potentials, Fig. 4, by linear regression of the Arrhenius plots, which are the insets of the figure. On both catalysts the apparent activation energy increases with increasing potentials; this fact reveals that the rate-limiting step is one related to ethanol adsorption [19]. Furthermore, lower activation energies are obtained with $\mathrm{PtSnNi} / \mathrm{C}$.

It is important to bear in mind that a good electrocatalyst towards the complete oxidation of ethanol to $\mathrm{CO}_{2}$ must facilitate the $\mathrm{C}-\mathrm{C}$ bond breaking, because $\mathrm{EO}$ proceeds via: i) the formation of adsorbed $\mathrm{CO}$ and $\mathrm{CHx}$ species, leading to electrode poisoning, and ii) the formation of an adsorbed species with two carbons, i.e., acetyl species, that can be dissociated on the electrode surface and converted in carbon dioxide after reaction with oxygenated species, or desorbed and transferred to the bulk as acetaldehyde and/or acetic acid [7].

In this respect, it must be noted that the adsorption and dehydrogenation of ethanol need Pt surface ensembles, which are less abundant at the alloy surfaces. Therefore, the fact that $\mathrm{PtSnNi} / \mathrm{C}$ shows a better performance for EO in acidic media than the PtSn/C catalyst can be attributed to a partial Ni dissolution, which could change the morphology of the catalyst clusters, increasing the presence of Pt ensembles for ethanol dehydrogenation and $\mathrm{C}-\mathrm{C}$ bond splitting, while $\mathrm{Ni}$ oxide and Sn oxide species provide the oxygenated species for the subsequent oxidation.

Another possible explanation for the better catalytic behaviour of $\mathrm{PtSnNi} / \mathrm{C}$ arises after considering that, in agreement with the electro-negativity series, an electron transfer from $\mathrm{Ni}$ and $\mathrm{Sn}$ to $\mathrm{Pt}$ can be possible. In consequence, it could be inferred that these electron transfers can also contribute to weakening the bond of PtCO-like species, assisting the conversion to $\mathrm{CO}_{2}$ [20]. Furthermore, it must be noticed that for $\mathrm{PtSnNi} / \mathrm{C}$ the existence of a surface layer containing $\mathrm{Ni}(\mathrm{OH})_{2}$ and/or $\mathrm{NiOOH}$ can be possible. Such a Ni-hydroxide layer on the PtSnNi catalyst may display high activity with respect to ethanol electrooxidation due to oxygen-containing species formed on the catalyst [21-23]. 

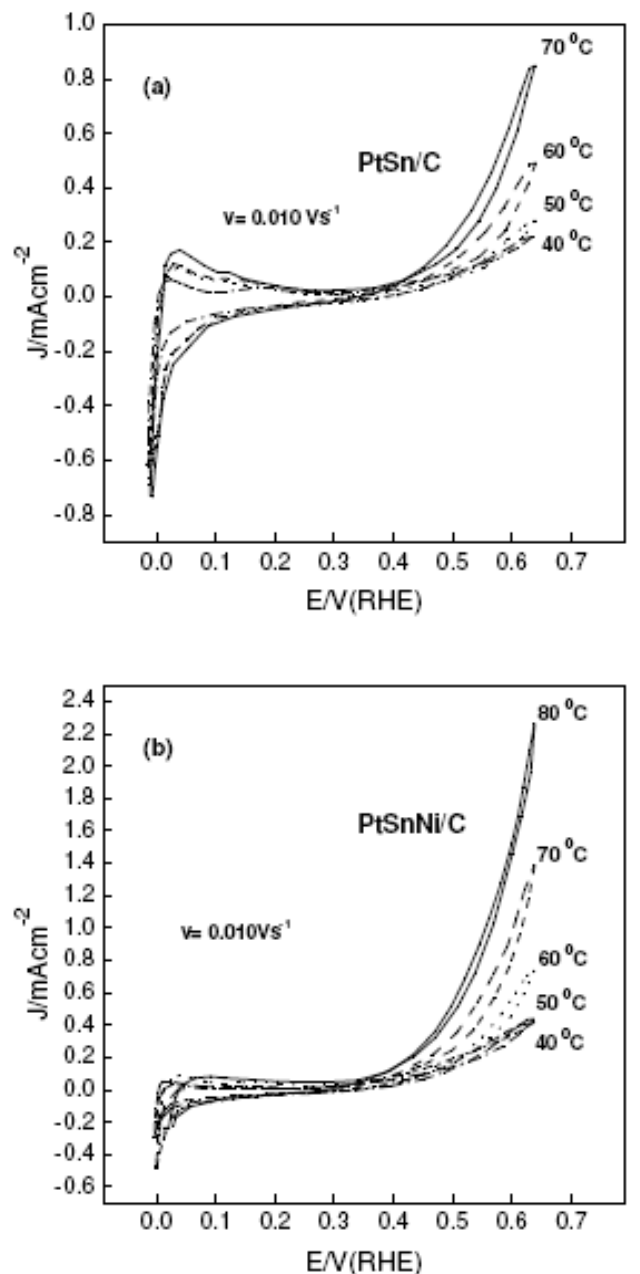

Figure 3. Cyclic voltammograms for EO $1 \mathrm{M} \mathrm{C}_{2} \mathrm{H}_{5} \mathrm{OH}+0.5 \mathrm{M} \mathrm{H}_{2} \mathrm{SO}_{4}$ at different temperatures on (a) $\mathrm{PtSnNi} / \mathrm{C}$ and (b) $\mathrm{PtSn} / \mathrm{C}$.

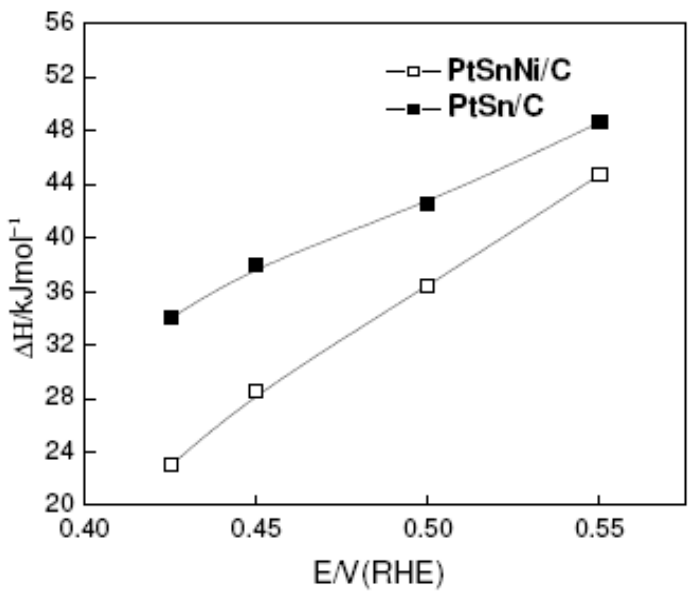

Figure 4. Arrhenius plots for $\mathrm{EO}$ on $\mathrm{PtSn} / \mathrm{C}$ and $\mathrm{PtSnNi} / \mathrm{C}$ at various potentials.

\section{Conclusions}

$\mathrm{PtSn} / \mathrm{C}$ and $\mathrm{PtSnNi} / \mathrm{C}$ catalysts synthesised by the polyol methodology were employed to determine their catalytic activity for ethanol electro-oxidation. The results indicate that the $\mathrm{PtSnNi} / \mathrm{C}$ catalyst performs better than the binary $\mathrm{PtSn} / \mathrm{C}$ 
catalyst due to the promoting effect of $\mathrm{Ni}$. Ni dissolution could change the morphology and accessibility of the catalyst clusters by increasing the number of $\mathrm{Pt}$ ensembles for ethanol dehydrogenation and $\mathrm{C}-\mathrm{C}$ bond splitting. Moreover, it is possible that $\mathrm{Ni}$ oxide species such as $\mathrm{NiO}, \mathrm{Ni}(\mathrm{OH})_{2}$ and $\mathrm{NiOOH}$, contribute to the oxidative removal of $\mathrm{CO}$ and $\mathrm{CH}_{3} \mathrm{CO}$ species adsorbed on adjacent $\mathrm{Pt}$ active sites, thus enhancing the activity for the electro-oxidation of ethanol at low potentials.

Summing up, the improved performance for EO obtained with $\mathrm{PtSnNi} / \mathrm{C}$ catalysts can be attributed to a cooperative effect between the numerous active $\mathrm{Pt}$ ensembles for ethanol dehydrogenation and $\mathrm{C}-\mathrm{C}$ bond rupture, and the larger $\mathrm{OH}$ availability.

\section{Acknowledgements}

The authors are grateful to Comisión de Investigaciones de la Provincia de Bs As (CIC) project C 2006-2007 and ANPCyT project PICT 10-13572 and CONICET for financial support. AMCL is member of the research career at CIC.

\section{References}

1. A.S. Aricò, S. Srinivasan, V. Antonucci, Fuel Cells 1 (2001) 133.

2. A.K. Shukla, R.K. Raman, Annual Review of Materials Research 33 (2004) 155.

3. A. Stassi, C.D’Urso, A. DiBlassi, V. Baglio, V. Antonucci, A.S. Arico, A.M. Castro Luna, A. Bonesi, W.E. Triaca, J. Appl. Electrochem. 36 ( 2006) 1143.

4. T. Iwasita, E. Pastor, Electrochim. Acta 39 (1994) 531.

5. C. Lamy, E.M. Belgsir, J.M. Leger, J. Appl. Electrochem. 31 (2001) 799.

6. G.A. Camara, T. Iwasita, J. Electroanal. Chem. 578 (2005) 315.

7. H. Wang, Z. Jusys, R.J. Behm, J. Power Sources 154 (2006) 351.

8. J.P.I. de Souza, S.L. Queiroz, K. Bergamaski, E.R. Gonzalez, F.C. Nart, J. Phys. Chem. B 106 (2002) 9825.

9. Hui-Fang Wang, Zhi-Pan Liu, J. Am. Chem. Soc.

10. E. Antolini, J. Power Sources 2007 (170) 1.

11. C. Lamy, S. Rousseau, E.M. Belgsir, C. Coutanceau, J.-M. Léger, Electrochim. Acta 49 (2004) 3901.

12. L Jiang, G. Sun, S. Sun, J. Liu, S. Tang, H. Li, B. Zhou, Q. Xin, Electrochim. Acta 50 (2005) 5384.

13. F. Colmati, E. Antolini, E.R. Gonzalez, Appl. Catalysis B: Environmental 73 (2007) 106.

14. M. Chen, Y. Xing, Langmuir 21 (2005) 9334.

15. A. Bonesi, G. Garaventa, W.E. Triaca, A.M. Castro Luna, Int. J. Hydrogen Energy 33 (2008) 3499.

16. A. Bonesi, G. Garaventa, W.E. Triaca, A.M. Castro Luna, Actas Hyfusen (2007) paper 13-03.

17. F. Colmati, E. Antolini, E.R. Gonzalez, J. Alloys and Compounds 456 (2008) 264. 
18. L. Jiang, L. Colmenares, Z. Jusys, G.Q. Sun, R.J. Behm, Electrochim. Acta 53 (2007) 377.

19. F. Ficiouglu, F. Kadirgan, J. Electroanal. Chem. 430 (1997) 179.

20. J.-H. Choi, K.-W. Park, B.-K. Kwon, Y.-E. Sung, J. Electrochem. Soc. 150 (2003) A973.

21. Z-B. Wang, G-P. Yin, J. Zhang, Y-Ch. Sun, P-F. Shi, J. Power Sources 160 (2006) 37.

22. E.V. Spinace, M. Linardi, A.O. Neto, Electrochem. Commun. 7 (2005) 365.

23. E. Ribadeneira, B.A. Hoyos, J. Power Sources 180 (2008) 238. 